\title{
THE CRITICAL REVIEW OF DEVELOPMENT THEORIES OF FOREIGN DIRECT INVESTMENT
}

\author{
[Kritický prehl’ad rozvojových teórií priamych zahraničných investícií] \\ Tomáš Dudáś ${ }^{1}$ \\ ${ }^{1}$ Ekonomická univerzita v Bratislava, Fakulta medzinárodných vzt’ahov, Dolnozemská cesta 1/b. 85235 \\ Bratislava 5 \\ Email:tomas.dudas@euba.sk
}

\begin{abstract}
Foreign direct investments play a crucial role in the global economy nowadays and they have the ability to boost economic development in less developed countries. The aim of the article is to critically review the most important theories that deal with the impact of FDI flows on economic development. Due to the limited space the article focuses on the three most important theories - on Raymond Vernon's product life cycle theory, on the Japanese FDI development theories and the FDI development theory of John Dunning. The results of our review show that although these theories failed to develop a universally acceptable framework, they can be certainly useful as theoretic framework for empirical research on country level. ${ }^{1}$
\end{abstract}

Keywords: economic development, foreign direct investments, FDI theories.

JEL classification: F21

Doručeno redakci: 13.5.2014; Recenzováno: 26.5.2014; 4.6.2014; Schváleno k publikování: 23.9.2014

\section{Úvod}

Globálna ekonomika prešla v posledných dekádach mnohými pozitívnymi zmenami. Napriek celkovému hospodárskemu pokroku však stále možno nájst' množstvo hospodársky zaostalých štátov a regiónov. Dôležitou otázkou ekonomickej vedy teda zostáva, ako hospodársky pozdvihnút' tieto štáty. Zároveň, aké faktory hrali najdôležitejšiu úlohu v hospodárskom rozvoji štátov, ktorým sa podarilo vymanit' z chudoby a zaostalosti. Ked’že v posledných desatročiach množstvo priamych zahraničných investícií (PZI) vo svetovom hospodárstve neustále rástlo, ekonómovia sa začali zaujímat aj o skúmanie PZI ako faktora hospodárskeho rozvoja. Výsledkom tohto záujmu boli rozvojové teórie priamych zahraničných investícií. Tieto teórie vychádzajú najmä $\mathrm{z}$ analýzy hospodárskeho rozvoja štátov, ktoré prijali väčšie množstvo PZI, pričom najčastejšie skúmaním regiónom sú novoindustrializované štáty juhovýchodnej Ázie.

Ciel'om tohto článku je kriticky preskúmat' najdôležitejšie rozvojové teórie PZI, ktoré v posledných desat'ročiach vznikli v ekonomickej vede. Rozsah článku nedovol’uje kompletný prehlad rozvojových teórií PZI, sústredíme sa preto na najdôležitejšie a najviac diskutované teórie. V článku sa postupne venujeme teórii životného cyklu Raymonda Vernona, hypotézam Kiyoshiho Kojimu skúmajúcim japonské PZI a ich vplyv na hospodársky rozvoj a úvahám Johna Dunninga o vzt’ahoch hospodárskeho rozvoja menej vyspelých štátov a priamych zahraničných investícií.

\footnotetext{
1 Článok bol spracovaný v rámci projektu KEGA 009EU-4/2013 „Vypracovanie komplexných učebných materiálov k predmetu teórie medzinárodných hospodárskych vzt’ahov orientovaných na ich aplikáciu v súčasnej svetovej ekonomike“, riešenom na Fakulte medzinárodných vzt’ahov Ekonomickej univerzity v Bratislave $\mathrm{v}$ rokoch 2013 a 2014.
} 


\section{Teória životného cyklu}

Teóriu životného cyklu možno považovat' za predchodcu modernejších teórií Kojimu a Dunninga. Ide o pomerne starú teóriu, ktorú vypracoval ešte v roku 1966 americký ekonóm Raymond Vernon. On prvýkrát vypracoval dynamickú teóriu PZI, v rámci ktorej analyzoval vzt'ahy tokov PZI a jednotlivých fáz životného cyklu výrobkov.

Podla tejto teórie výrobca ponúka svoj produkt najprv na domácom trhu a vyrába ho tiež doma. Riziko prenosu výroby do zahraničia je ešte príliš vysoké a aj záujem o produkt v zahraničí je nižší. K zmene však dôjde, ak je produkt na domácom trhu úspešný. Domáci trh už po určitom čase nedokáže saturovat' viacej výrobkov, a preto firmy využívajú zahraničné trhy na d'alšie rozšírenie výroby. Výroba sa však ešte aj v tomto štádiu uskutočňuje doma, firma vstupuje na zahraničné trhy nepriamo prostredníctvom exportu.

Ďalšie štádium je štádium zrelosti výrobku a práve v tomto štádiu príde podl'a Vernona chvíl'a, ked' výrobca prenáša aj samotnú výrobu do zahraničia. Robí tak preto, lebo prenosom výroby dosahuje určitú konkurenčnú výhodu - nižšie náklady, l'ahší prístup na trh, obchádzanie prekážok zahraničného obchodu. atd'. Toto je štádium, ked' dochádza k priamym investíciám v zahraničí. Zároveň firma už pripravuje zavedenie inovovaného výrobku na domácom trhu, ktoré zabezpečí firme zachovanie svojej trhovej pozície. Otázkou je, kedy prichádza $\mathrm{k}$ tomu kl'účovému momentu, že sa firma rozhodne otvárat' výrobné aktivity aj v zahraničí. Podl'a Vernona ide o komplexné rozhodnutie, ktoré je závislé od hlavne od nákladov výroby v zahraničí a dopravných nákladov. Kým marginálne náklady domácej výroby spolu s dopravnými nákladmi sú nižšie než priemerné výrobné náklady v zahraničnej prevádzke firmy sa budú investícii vyhýbat'. Samozrejme, vel’a závisí od charakteristiky ciel'ovej krajiny a od schopnosti firmy využit' svoje znalosti a technológie v tejto krajine.

Na PZI tohto typu možno nájst’ množstvo príkladov. Každá firma, ktorá prerastie svoju domácu ekonomiku, $\mathrm{v}$ istom momente začne uvažovat' o rozšírení aktivít $\mathrm{v}$ zahraničí. Globálny automobilový priemysel v posledných dekádach prešiel práve touto fázou. Najväčší výrobcovia automobilov sa snažili pretransformovat' $\mathrm{z}$ národných/regionálnych hráčov na globálne firmy, a preto sa $\mathrm{v}$ istom momente nevyhli zakladaniu výrobných kapacít mimo svojho štátu. Firma Hyundai Motor Group (koncern, ktorý združuje značky Hyundai a Kia) je v súčasnosti asi najdynamickejšie rastúcou automobilkou sveta, pričom v roku 2012 vyrobila viac než 7 miliónov automobilov. Firma pritom prešla vel'mi rýchlym vývojom, ked' pred dvadsiatimi bol Hyundai na globálnej úrovni takmer neznámym výrobcom. Skupina Hyundai začala svoje výrobky predávat' v USA až v roku 1986 a v Európe sa objavila až v 90. rokoch. Obchodné úspechy na konci 90 . rokov a na začiatku 21. storočia však firmu prinútili k tomu, že bola nútená postavit' viacero výrobných závodov na ciel'ových trhoch. Dnes má skupina Hyundai/Kia v Európe výrobné závody v Českej republike, na Slovensku, v Rusku a $v$ Turecku a dizajnérske centrum v Nemecku. V USA vlastní skupina dva výrobné závody (Kia-Georgia a Hyundai-Alabama) a dizajnérske centrum v Kalifornii. Je viditel'né, že $\mathrm{v}$ dnešnom globálnom svete je po istom bode rastu medzinárodná výrobná prítomnost' nevyhnutnost'ou.

Podla Vernona sú však PZI typické nielen vo fáze rastu, ale aj vo fáze poklesu. V týchto prípadoch často dochádza $\mathrm{k}$ d'alšiemu presunu výroby (najmä) do rozvojových štátov, kde vd’aka extrémne nízkym nákladom a menšej náročnosti spotrebitel'ov môže aj relatívne zastaraný produkt prinášat' d’alšie zisky. Výroba mobilných telefónov môže slúžit' ako dobrý príklad. Aj ked' dnes všetci hovoria o smartfónoch, najväčšiu čast' predaja mobilných telefónov tvoria stále lacné modely bez dotykového displeja či možnosti videotelefonovania. Tieto modely sa predávajú najmä v chudobnejších rozvojových štátoch a ich výroba sa pre 
uchovanie nízkych cien uskutočňuje taktiež v týchto štátoch. Ďalším príkladom môže byt' slávny Volkswagen chrobák, ktorý v 60. rokoch minulého storočia postupne začal zaostávat' za svojimi konkurentmi na trhoch $\mathrm{v}$ priemyselne vyspelých štátoch. Firma Volkswagen preto európsku výrobu modelu postupne utlmoval a v roku 1978 úplne zastavila. Volkswagen si však plne uvedomoval potenciál modelu na trhoch chudobnejších štátov, preto svoje výrobné kapacity premiestnila do Brazílie a Mexika. Chrobák zostal vo výrobe v Južnej Amerike dlho po tom, ked' bola výroba v Európe zastavená a posledný kus bol vyrobený v Mexiku v roku 2003.

Ked’že Vernonove myšlienky pochádzajú ešte z 60. rokov minulého storočia, otázkou je, či sú jeho závery relevantné aj $v$ dnešnej globálnej ekonomike. Platnost' tejto teórie je v súčasnosti už otázna. Ak berieme do úvahy povahu firiem investujúcich v zahraničí, táto teória má stále platnost' pre firmy vo fáze rastu, ktoré práve uskutočňujú svoju medzinárodnú expanziu. Spomenuli sme už skupinu Hyundai/Kia, ktorá sa pretvorila zo silnej národnej firmy na globálnu nadnárodnú korporáciu. Podobných príkladov by sme vo svetovom hospodárstve našli ešte vel'ké množstvo, hlave $\mathrm{v}$ prípade ambicióznych firiem pochádzajúcich z juhovýchodnej Ázie alebo Latinskej Ameriky.

Platnost' myšlienok Vernona je však vel'mi limitovaná v prípade zahraničných investícií už etablovaných nadnárodných korporácií, ktoré uskutočňujú tzv. globálny sourcing. V prípade týchto korporácií už životný cyklus výrobku nehrá relevantnú úlohu pri rozhodnutiach o ich PZI. Globálne korporácie často vyrábajú svoje výrobky v zahraničí už od prvého momentu ich uvedenia na trh, pričom samotné uvedenie na trh je medzinárodné alebo priamo globálne. Apple, jedna z najobdivovanejších firiem súčasnosti, vyrába takmer všetky svoje výrobky v juhovýchodnej Ázii pomocou externej firmy Foxconn a jej domáce výrobné kapacity de facto neexistujú. Podobná je situácia aj d’alších globálnych firiem, ktoré už preniesli výrobný proces na externé firmy.

Od publikácie článku Raymonda Vernona sa svetové hospodárstvo výrazne zmenilo a dnešná globálna ekonomika funguje podl'a iných pravidiel ako v 60. rokoch minulého storočia. Napriek tomu sú niektoré závery Vernona stále platné. Záujem je myšlienky Raymonda Vernona je stále vel'ký, jeho článok z roku 1966 patrí medzi najcitovanejšie články v modernej histórii ekonomickej vedy.

Nesporným faktom však je, že na teórii životného cyklu boli založené d'alšie teórie zamerané na oblast' PZI, napríklad model Paula Krugmana, ktorý sa pomocou teórie životného cyklu snažil vysvetlit' procesy inovácie a imitácie výrobkov v priemyselne vyspelých štátoch a v rozvojových štátoch. Krugman prišiel s hypotézou, že iba menšia čast' výrobkov sa vyrába v priemyselne vyspelých štátoch, ked' sa pomocou procesu imitácie výroba rýchlo presúva do rozvojových štátov. Priemyselne vyspelé štáty teda exportujú inovatívne produkty a rozvojové štáty zastaranejšie staršie produkty.

\section{Japonské rozvojové teórie PZI}

Priame zahraničné investície začali hrat' relevantnejšiu úlohu vo svetovom hospodárstve až od 70. rokoch minulého storočia, pričom prvé teórie, ktoré skúmali vzt'ahy tokov PZI a hospodárskeho rozvoja vznikli v Japonsku. Nejde pritom o náhodu, dynamický rozvoj japonských firiem a zmena strategického smerovania japonskej ekonomiky zapríčinili výrazný rast japonských PZI v regióne juhovýchodnej Ázie. Tieto trendy následne vzbudili záujem japonských ekonómov, ktorí začali skúmat' vplyvy týchto investícií. 
Základy japonských rozvojových teórii PZI položil Kiyoshi Kojima v 70. rokoch 20. storočia, ked'sa venoval skúmaniu priamych zahraničných investícii japonských firiem a vyslovil hypotézu, že japonské PZI sa líšia od amerických PZI. Podl'a neho japonské PZI vytvárajú tovarové toky, kým americké PZI nahrádzajú tovarové toky (Kojima, 1975). Japonské investície dokázali lepšie využit komparatívne výhody jednotlivých štátov v juhovýchodnej Ázii. Japonské priame zahraničné investície v prvej fáze investovania podporovali presun priemyselných odvetví náročných na prácu alebo citlivých na životné prostredie.

Japonské rozvojové teórie PZI d’alej rozvinul americký ekonóm japonského pôvodu Terutomo Ozawa. On medzi prvými vyslovil tézu, že ak sa rozvojové štáty chcú pohnút' ekonomicky smerom dopredu, je nutné, aby otvorili svoje hospodárstva a zamerali sa na ziskavanie PZI. Ozawa píše, že rozvojové štáty musia vstupovat' do interakcie S rozvinutejšími ekonomikami a postupne preberat' ich know-how a znalosti. Ilustruje to na príklade USA, ktoré v 19. storočí iba kopírovali úspešné kroky Vel'kej Británie a na príklade Japonska, ktoré po druhej svetovej vojne úspešne emulovalo výsledky priemyselne rozvinutých štátov (Ozawa, 1992).

Ozawa skúmal vzt’ahy akumulácie fyzického a l'udského kapitálu, stupňa hospodárskeho rozvoja a PZI. Pri svojom skúmaní Ozawa využil model Michaela Portera (1990), ktorý skúmal konkurenčné výhody štátov. Porter identifikoval štyri rozvojové fázy (fázy konkurencieschopnosti) - fázu založenú na výrobných faktoroch, fázu založenú na investíciách, fázu založenú na inováciách a fázu založenú na bohatstve. Ozawa využil tieto fázy a skúmal prílev a odlev PZI v jednotlivých fázach hospodárskeho rozvoja. Identifikoval tri základné vývojové stupne:

- na prvom vývojovom stupni prichádzajúce investície hladajú výhodné výrobné faktory a odchádzajúce investície sú zatial' nepodstatné,

- na druhom vývojovom stupni prichádzajúce investície sú zamerané na rastúce domáce trhy a odchádzajúce investície sú motivované najmä lacnou pracovnou silou,

- na tret'om vývojovom stupni sú tak prichádzajúce, ako aj odchádzajúce investície motivované trhovými a technologickými faktormi.

Na prácu Kojimu a Ozawu nadviazal Rajneesh Narula (1996), ktorý využival rámec OLI teórie a analyzoval dynamiku vztahu medzi špecifickými výhodami firiem a nemobilnými výhodami štátov. Podl'a neho na začiatku hospodárskeho rozvoja disponujú štáty najmä prírodnými zdrojmi a ich PZI sú ovplyvnené najmä nimi. Faktory pôsobiace na PZI sa však menia, ak štáty prechádzajú na vyšší stupeň hospodárskeho rozvoja. Na najvyššom stupni sú PZI ovplyvnené už najmä vytvorenými aktívami, akými sú l'udské zdroje a infraštruktúra.

Platnost' úvah japonských ekonómov bola potvrdená niekol'kokrát aj empiricky. Prvým príkladom je vývoj japonskej ekonomiky, ktorá tvorila základ teoretických hypotéz (a jej vývoj dokumentuje tabul'ka 1). Rovnaké tendencie je však možné dokumentovat' aj v iných štátoch juhovýchodnej Ázie, ked' vhodným príkladom je Južná Kórea, ktorej firmy patria medzi najdynamickejšie sa rozvíjajúce sa na svete. Podobný vývoj je možné pozorovat' v prípade čínskych korporácií, ktoré po fáze licenčnej spolupráce a spoločných podnikov začínajú expandovat' pomocou PZI v zahraničí. V poslednom období bolo možné registrovat' výrazný prienik čínskych spoločností medzi najväčšie globálne korporácie, čoho dôkazom je napríklad prítomnost' 89 čínskych firiem na zozname najväčších firiem na svete Fortune Global 500 z roku 2013. 
Nie všetky ekonomiky sú však schopné prejst' fázami, ktoré načrtli Ozawa a d’alši teoretici. $V$ tomto kontexte možno identifikovat' dva klúčové faktory - vel'kost' ekonomiky a schopnost' štátu napomáhat' tvorbe silných domácich korporácii. Tieto faktory hovoria $\mathrm{v}$ prospech štátov juhovýchodnej Ázie, ked’že väčšinou ide o l'udnaté krajiny s pomerne silnými zásahmi štátu do ekonomiky. Ak sa pozrieme na Južnú Kóreu, 50-miliónový dynamicky rastúci domáci trh bol dobrou základňou pre vývoj silných domácich podnikov a kórejské vlády protekcionistickými opatreniami ich pozíciu d’alej posilňovali.

Tabul'ka 1: Fázy hospodárskeho rozvoja podl’a Ozawu na príklade Japonska
I. fáza - 50. roky - polovica 60. rokov
- Expanzia priemyselných odvetví náročných na pracovnú silu (napr. textilný priemysel, obuvníctvo)
- Táto fáza bola sprevádzaná selektívnym importom výrobných technológií a nákupom technológií a licencií. Na konci tejto fázy sa začal postupný presun priemyselných odvetví náročných na pracovnú silu do susedných štátov juhovýchodnej Ázie
II. fáza - koniec 50. rokov - začiatok 70. rokov
- Rozvoj t’ažkého priemyslu - výroba ocele, strojárenstvo, lodiarenský priemysel, petrochémia atd'.
- Táto fáza sa vyznačovala zrýchl'ujúcim sa preberaním technológií z priemyselne vyspelých štátov (USA a západná Európa) najmä pomocou licencií, čoraz dôležitejšiu úlohu však zohrávali spoločné podniky (joint-ventures).
- Odchádzajúce PZI boli v tomto období zamerané na využívanie lacných zdrojov.
III: fáza - koniec 60. rokov - 90. roky
- Rýchly rozvoj modernej hromadnej priemyselnej výroby - napr. automobilový priemysel a elektrotechnický priemysel.
- Postupná adaptácia a vylepšovanie zahraničných technológií viedla k rastúcim PZI v oblasti automobilového a elektrotechnického priemyslu (najmä v USA a v západnej Európe).
IV. fáza - koniec 80. rokov - súčasnost'
- Rozvoj flexibilnej priemyselnej výroby založenej na mechatronike.
- Rýchle inovácie v oblasti elektroniky, IT, nových materiálov, biotechnológií a v iných oblastiach.
- Japonské spoločnosti vytvárajú svoje výrobné a inovačné siete a uzatvárajú strategické aliancie v USA, v Európe a v juhovýchodnej Ázii.

Zdroj: OZAWA, T. (1992): Theory of FDI as a Dynamic Paradigm of Economic Development. In: Transnational Corporations, 1992, r. 1, č. 1, s. 27-54.

Na druhej strane, štáty strednej Európy sa len t’ažko dostanú na vývojový stupeň so silným odlevom PZI, ked’že na malých domácich trhoch len t’ažko vznikajú nadnárodné korporácie a vlády sa zameriavajú skôr na podporu prílevu PZI od zahraničných nadnárodných korporácí́.

\section{Dunningova teória PZI a hospodárskeho rozvoja}

John Dunning sa popri svojej najznámejšej eklektickej teórii PZI (ktorá je v našich zemepisných šírkach najlepšie rozpracovaná a známa, a preto sa ňou v článku nezaoberáme ${ }^{2}$ ) venoval aj skúmaniu PZI a hospodárskeho rozvoja na všeobecnej úrovni, pričom jeho prístup je podobný prístupu japonských ekonómov. Jeho teória načrtáva základné vzt’ahy medzi tokmi a štruktúrou PZI a fázami hospodárskeho rozvoja jednotlivých štátov.

\footnotetext{
${ }^{2}$ Pozri napríklad Dudáš, 2006 alebo Grančay, Szikorová, 2014.
} 
Dunning rozoznáva pät' základných vývojových fáz, ktorými štáty pri investovaní do zahraničia prechádzajú (Dunning, 1981):

- V prvej fáze štáty neinvestujú v zahraničí, ked’že kvôli svojej nízkej rozvinutosti nedokážu využit' svoje špecifické prednosti. Do medzinárodného podnikania sa domáce firmy zapájajú len prostredníctvom vývozu. Vel'kú úroveň v tejto fáze hrajú PZI zo štátov na vyššom stupni hospodárskeho rozvoja, ktoré si začínajú všímat' špecifické výhody týchto štátov a snažia sa ich využit' a rozvinút'.

- V druhej fáze dochádza $\mathrm{k}$ rastu PZI prúdiacich do štátu. Začína rást' kúpna sila obyvatel'ov, a to si všímajú zahraničné firmy, ktoré nahrádzajú dovoz výrobou na mieste. Daný štát však v zahraničí investuje len zriedka, domáce firmy ešte nedisponujú špecifickými výhodami, ktoré by mohli využit'.

- V tretej fáze začínajú viditel'ne rást' investície firiem daného štátu smerujúce do zahraničia. Domáce firmy už získali dostatočné skúsenosti v medzinárodnom podnikaní a vypracovali svoje špecifické výhody. Dochádza k rastu miezd a štát stráca výhodu lacnej pracovnej sily. Nastupujú však nové výhody - vysoký dopyt, technologický rozvoj, moderná infraštruktúra a pod. Odlev investícií je ešte nižšśí než prílev, ale objem prílevu a odlevu sa už začínajú zbližovat'.

- Vo štvrtej fáze sa štát stáva výrazným vývozcom priamych zahraničných investícií.

- Piata fáza sa podl'a Dunninga vyznačuje intraindustriálnou produkciou. Rozhodnutia o PZI sú už menej podmienené špecifickými výhodami jednotlivých štátov, viac sa prihliada na dynamické faktory. Dovozné a vývozné investície konvergujú. Podl'a Dunninga je táto fáza v súčasnosti charakteristická pre najvyspelejšie štáty vo svetovej ekonomike.

Je zretel'né, že Dunning vidí úlohu PZI pri hospodárskom rozvoji rovnako ako zástupcovia japonských rozvojových teórií (čo nie je prekvapením, ked’že s Narulom často vedecky spolupracoval). Aj on pokladá PZI za vel'mi užitočný nástroj, ktorý dokáže pomôct' pri štartovaní hospodárskeho rozvoja chudobných štátov. Ak sa však pozrieme na jednotlivé fázy hospodárskeho rozvoja hlbšie, vidíme, že pri prechode z jednej rozvojovej fázy do druhej dôležitú úlohu hrá štátna hospodárska politika. V prvej fáze stačia opatrenia na podporu prílevu PZI, ak však chce štát dosiahnut' silné odchádzajúce PZI, je nutné budovat' silné domáce korporácie. Ak totiž domácu ekonomiku ovládnu zahraničné nadnárodné korporácie, odchádzajúce PZI zostanú dlhodobo na nízkej úrovni, ked’že nadnárodné korporácie uskutočňujú svoje PZI prostredníctvom materskej firmy. 
Obrázok 1: Toky PZI v Japonsku, v Číne a v Južnej Kórei v rokoch 1995 - 2005 (mil. USD)

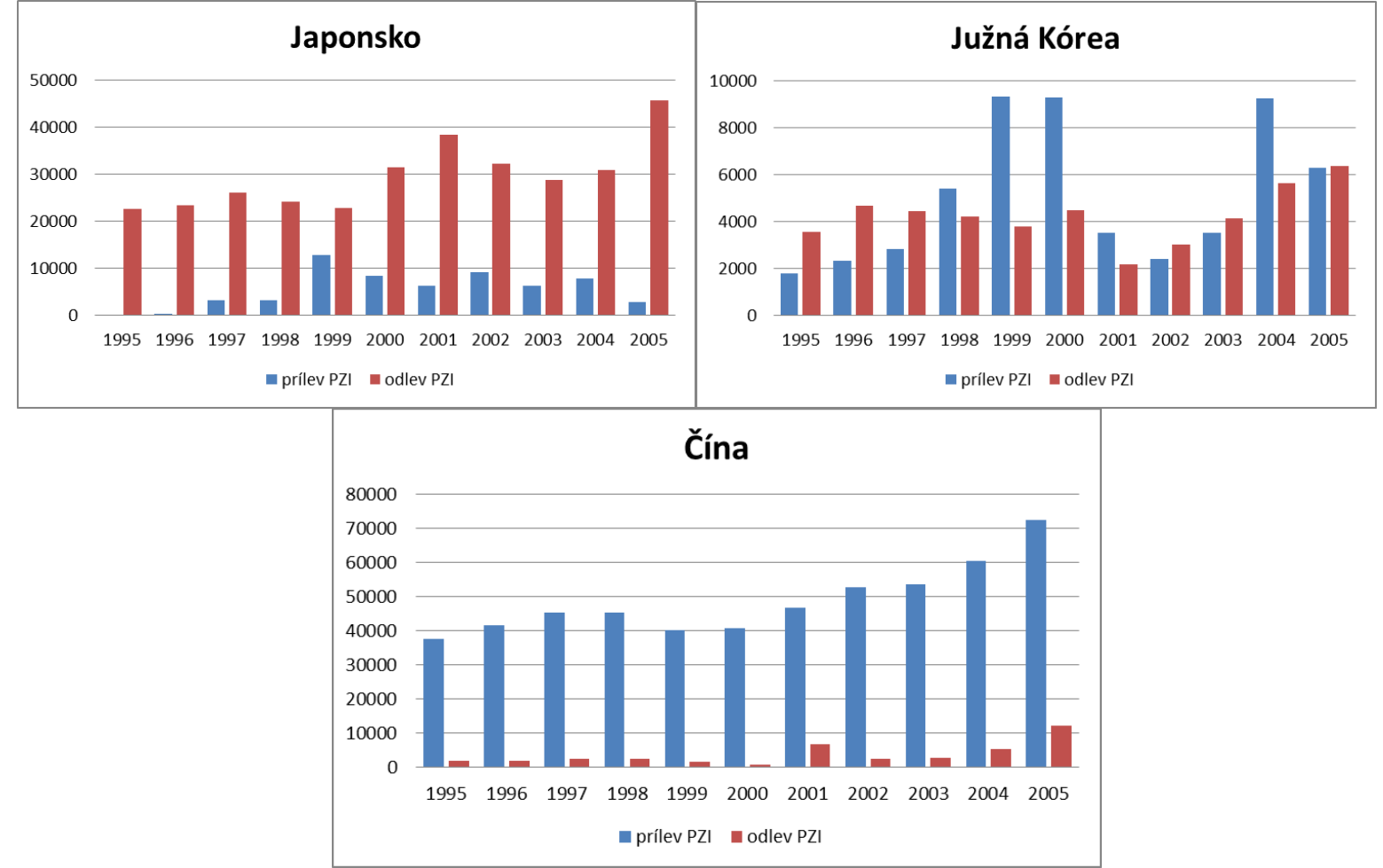

Zdroj: On-line štatistická databáza UnctadStat dostupná na http://unctadstat.unctad.org/

Dôkazom tohto tvrdenia sú štáty juhovýchodnej Ázie. Južná Kórea dlhé obdobie obmedzovala prístup zahraničných spoločností na svoj trh a pomocou protekcionistickej hospodárskej politiky budovala silné domáce megakorporácie (chaeboly - Samsung, LG, Daewoo), ktoré sú v súčasnosti už rovnocenným konkurentom nadnárodných spoločností pochádzajúcich $\mathrm{z}$ tradičných hospodársky vyspelých štátov. Juhokórejské firmy v poslednej dekáde silne expandovali na svetových trhoch, čoho dôkazom sú napríklad investície kórejských spoločností na Slovensku (Kia a Samsung). Podobnú hospodársku stratégiu uskutočňuje aj Čína, ktorá dlhodobo vyžaduje od zahraničných investorov, aby si pri svojich projektoch zobrali za partnera domácu firmu (joint venture). Týmto dochádza k posilneniu domácich firiem, ktoré získajú nové technológie, manažérske know-how a iné znalosti. $\mathrm{Z}$ tohto procesu postupne rástli silné čínske korporácie, ktoré sú dnes už sami kl'účovými hráčmi na globálnych trhoch.

Štáty nachádzajúce sa $v$ rôznych vývojových fázach môžeme vidiet' na obrázku 1, ktorý zobrazuje toky PZI v troch krajinách východnej Ázie - v Japonsku, v Južnej Kórei a v Ćíne v rokoch 1995 až 2005. V prípade Japonska už vidíme krajinu v najvyššej dunningovskej fáze. Ide o krajinu s vysokým odlevom PZI na úrovni desiatok miliárd USD ročne, pričom prílev PZI je pomerne nízky a kolísavý. V tomto čase už Japonsko disponovalo vel'kým množstvom nadnárodných korporácií, ktoré patrili medzi najsilnejších hráčov vo svojom odvetví na svetovej úrovni. Oproti tomu, Južná Kórea je v rovnakom čase o stupeň nižšie. Krajina získava pomerne vel'ké množstvo PZI, ale už možno pozorovat' pomerne dynamický rast ich odlevu. Tento rast je obzvlášt' viditel'ný v rokoch $2001-2005$, čo korešponduje s obdobím, ked' viaceré kórejské korporácie sa začali menit' na globálne firmy (Samsung, Hyundai, Kia). Tento proces vyžadoval extenzívne budovanie výrobných a iných kapacít v zahraničí, čo sa odzrkadlilo aj v celkovom množstve kórejského PZI investovaného v zahraničí. 
Obrázok 2 : Toky PZI v Číne v rokoch 2006 - 2011 (mil. USD)

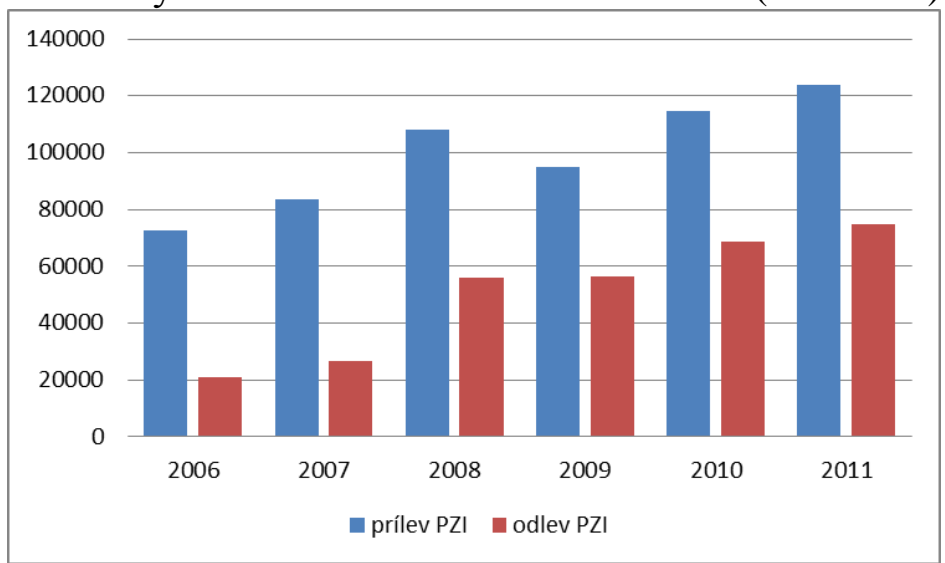

Zdroj: On-line štatistická databáza UnctadStat dostupná na http://unctadstat.unctad.org/

Čínske dáta o tokoch PZI z rovnakého obdobia rozprávajú iný príbeh. V druhej polovici 90. rokov minulého storočia sa Čína premenila na jednu z najatraktívnejších destinácií pre PZI v globálnom meradle. Bolo pritom možné už pozorovat' posun z prvej fázy do druhej, ked' dôležitým faktorom pre zahraničných investorov sa stávala rastúca kúpna sila čínskych spotrebitel'ov. Ako vidíme na grafe, odchádzajúce PZI v tomto čase ešte neboli príliš vysoké, ked’že silné domáce firmy sa iba $\mathrm{v}$ tom čase formovali. V druhej polovici skúmaného obdobia však už bolo možné pozorovat' rast odchádzajúcich čínskych PZI, pričom tento trend ešte viac posilnil po roku 2005 (obrázok 2). V prípade Č́ny je možné najlepšie pozorovat', ako sa trajektória ekonomického rozvoja pohybuje presne na dráhe, ktorú identifikoval John Dunning.

Čo sa týka nášho regiónu, štáty strednej a východnej Európy naopak z rôznych dôvodov rezignovali na podporu silných domácich firiem, čo viedlo $\mathrm{k}$ tomu, že vel'ké domáce spoločnosti boli v procese privatizácie odkúpené vel'kými nadnárodnými korporáciami. Je však nutné dodat', že v danom časovom okamihu chýbal domáci kapitál na privatizáciu a úspešné riadenie týchto firiem, čo možno dokumentovat’ aj zlyhaním tvorby silnej domácej podnikatel'skej vrstvy na Slovensku medzi 1994 a 1998.

Vel'ké nadnárodné spoločnosti nevyužívajú svoje dcérske spoločnosti na investičné aktivity, preto sú $\mathrm{v}$ súčasnosti odchádzajúce PZI zo štátov strednej a východnej Európy nízke. Výnimku tvoria len ruské energetické spoločnosti, česká ČEZ a dve mad'arské spoločnosti MOL (ropná spoločnost') a OTP Banka. Tieto spoločnosti nemajú dominantného zahraničného vlastníka a vlastnia ich domáci i zahraniční finanční investori, ktorí ponechávajú vol'nost' strategickým rozhodnutiam vedenia spoločnosti. Výsledkom je to, že tieto spoločnosti sa výrazne angažujú v priestore strednej a východnej Európy, ked' sa snažia vybudovat' pozíciu silnej regionálnej nadnárodnej spoločnosti.

Čo sa týka Slovenska, nedostatok silných domácich firiem sa v odleve PZI stále silne prejavuje. To znamená, že v dohl’adnej budúcnosti nie je možno očakávat', že Slovensko prejde vývojovou dráhou, ktorú načrtol John Dunning. To však neznamená, že by sme mali rezignovat' na podporu domácich podnikov, ked’že aj malá skupina medzinárodne úspešných podnikov môže byt' dôležitým faktorom hospodárskeho rozvoja. Slovenská softvérová firma ESET sa napríklad zaradila medzi kl'účových hráčov na trhu s antivírovým a bezpečnostným softvérom a dnes má prevádzky v USA (San Diego), v Argentíne (Buenos Aires) a v Singapure. Ide pritom o high-tech firmu s vysokou pridanou hodnotou a so vzdelanou 
pracovnou silou. Ak chce Slovensko postúpit’ na najvyššie rozvojové stupne, slovenské vlády sa budú musiet' zameriavat' na podporu práva podnikov takéhoto typu.

\section{Záver}

Skúmanie rozvojových teórií PZI prinieslo zmiešané výsledky. Realitou je, že teórie Vernona, Kojimu alebo Dunninga nedokázali poskytnút' všeobecne platné odpovede na otázky vzt'ahu PZI a hospodárskeho rozvoja. Modely, ktoré vypracovali Kojima alebo Dunning vel'mi dobre vysvetl'ujú zmeny, ktoré sa uskutočnili v štátoch juhovýchodnej Ázie, sú však použitel'né iba pre špecifickú skupinu štátov. Problematické sú pritom najmä malé ekonomiky, čo sme demonštrovali aj na príklade Slovenska. Problémom týchto teórií je aj to, že vznikli ešte v 60 ., 70. a 80. rokoch minulého storočia a fungovanie svetového hospodárstva od tej doby sa výrazne zmenilo.

To však neznamená, že by sme mali tieto teórie úplne zavrhnút' a nechat' upadnút' do zabudnutia. Niektoré aspekty teórie životného cyklu sú platné aj v dnešnej globálnej ekonomike a aj modely Kojimu a Dunninga sú použitel'né na empirické skúmanie vzt'ahu tokov PZI a hospodárskeho rozvoja danej krajiny. Naviac, teórie tohto druhu sú stále potrebné, ked’že v súčasnosti čoraz väčšie množstvo PZI smeruje práve do menej rozvinutých krajín. Možno ale prišiel čas na vznik nového teoretického prístupu, ktorý by vychádzal z predpokladov moderného globálneho hospodárstva 21. storočia.

\section{Literatúra}

[1] DUDÁS̆, T., 2006. Priame zahraničné investície vo svetovom hospodárstve. Bratislava: Ekonóm. ISBN 80-225-2139-6.

[2] DUNNING, J. H., 1981. Explaining the International Direct Investment Position of Countries: Towards a dynamic and development approach. Weltwirtschaftliches Archiv, 117(1), 30-64. ISSN 1610-2878.

[3] FORTUNE, 2014. Fortune Global 500 [online]. [cit. 11.4.2014]. Dostupné z: http://fortune.com/global500/

[4] GRANČAY, M. a N. SZIKOROVÁ, 2014. Determinanty čínskych priamych investícií v Afrike. Ekonomický časopis, 62(3), 307-325. ISSN 0013-3035.

[5] KOJIMA, K., 1975. International Trade and Foreign Direct Investment: Substitutes or Complements. Hitotsubashi Journal of Economics, n. 16, 1-12. ISSN 0018-280X.

[6] NARULA, R. and J. H. DUNNING, 1996. The Investment Development Path Revisited: Some Emerging Issues. Foreign direct investment and governments: catalysts for economic restructuring. Routlege. ISBN 0-203-43020-4.

[7] OZAWA, T., 1992. Theory of FDI as a Dynamic Paradigm of Economic Development. Transnational Corporations, 1(1), 27-54. ISSN 1014-9562.

[8] PORTER, M. E., 1990. The competitive advantage of nations. Harvard Business Review, 68(2) (March-April 1990), 73-93. ISSN 0017-8012.

[9] UNCTAD, 2014. UNCTAD STAT [online]. [cit. 24.3.2014]. Dostupné z: http://unctadstat.unctad.org

[10] VERNON, R., 1966. International Investment and International Trade in the Product Cycle. Quarterly Journal of Economics, 80(2), 190-207. ISSN 0033-5533. 